\title{
PERILAKU KONSUMTIF BERDASAR LOCUS OF CONTROL PADA REMAJA PUTRI
}

\author{
Lina \\ Haryanto F, Rosyld \\ Universitas Gadjah Mada
}

\begin{abstract}
INTISARI
Tujuan yang ingin dicapai dari penefitian ini ialah mengetahui adanya perbedaan perilaku konsumtif remaja puti yang berovientasilocus d control internal dengan yang berorientasi ekstemal. Hipotesis yang diajukan ialah terdapai perbedaan perilaku konsumif antara remaja ber-loc internal dengan remaja ber-toc eksternal.

Subjek penelitian ialah siswa-siswa kelas II berusia antara 16 sampai dengan 18 tahun pada sebuah SMU swasta khusus putri di Kodya Yog yakarta. Data diperoleh melalui penggumaan angket perilaku konsumtit, dan skala IPC-LOC, serta angket mengenai kepernilikan uang saku siswa. Analisis data menggunakan program analisis kovariansi.

Hasil analisis data menunjukkan ada perbedaan ( $F=27,788 ; p<0$ or).

Subjok ber-loc intemal mempunyai. rerata perilaku konsumtif $\left(M_{u \text { uf }}=59,064\right)$

lebih rendah dari pada kelompok subjek ber toc eksternal ( $M_{\text {ets }}=79,023$ ).

Hasil mi membuktikan bahwa locus of control berperan di dalam munculnya perilaku konsumtif pad a remaja putri.
\end{abstract}

Kata kunci: perilaku konsumtif, locus of control, remaja putri

Lina adalah alumnus Fakultas Psikologi Universitas Gadjah Mada Yogyakarta.

Haryanto F. Rosyid adalah dosen tetap Fakultas Psikologi UGM meminati kajian psikologi industri dan psikologi konsumen.

\section{PENGANTAR}

Perekonomian Indonesia pada saat ini dapat dikatakan sud ah cukup maju. Keadaan ini dapat dilihat dari pergeseran-pergeseran dalam bidang ekonomi yang sudah mulai tampak jelas. Indonesia sebagai negara agraris sedikit demi sedikit bergeser meninggalkan pola kehidupan pertanian menuju tatanan yang berpegang pada prinsip ekonomi industri. Secara keseluruhan dapat dikatakan bahwa kemajuan yang telah dicapai dalam bidang sosial ekonomi turut meningkatkan taraf kehidupan masyarakat indonesia. 
Dewasa ini berbagai macam produk ditawarkan kepada konsumen. Produk-produk in bukan hanya barang yang dapat memuaskan kebutuhan seseorang, tetapi terutama produk yang dapat memuaskan kesenangan konsumen. Informasi mengenai produk, baik melalui ikıan, promosi langsung maupun direct seling, berkembang semakin bervariasi, gencar dan menggunakan teknologi mutakhir yang sangat canggih. Kebia. saan dan gaya hidup orang juga berubah dalam jangka waktu yang relatif singkat menuju ke arah kehidupan mewah dan cenderung berlebihan, yang pada ujung-ujungnya menimbulkan pola hidup konsumtif.

Gejala-gejala ini mengindikasikan adanya kecenderungan perilaku konsumtif. Predikat konsumtif biasanya melekat pada seseorang bila orang tersebut membeli sesuatu di luar kebutuhan yang rasional, sebab pembelian tidak lagi didasarkan pada faktor kebutuhan, tetapi sudah pada taraf keinginan yang berlebihan. Lubis (1987) mengatakan bahwa perilaku konsumtif adalah suatu perilaku membeli yang tidak lagi didasarkan pada pertimbangan yang rasional melainkan karena adanya keinginan yang sudah mencapai taraf yang sudah tidak rasional lagi.

Remaja sebagai saiah satu goiongan da lam masyarakat, tidak lepas dari pengaruh konsumtivisme ini, sehingga tidaklah aneh jika remaja menjadi sasaran berbagai produk perusahaan (Jatman, 1987). Kenyataan menunjukkan bahwa gerakan gaya hidup mewah atau konsumtif ini juga dilakukan oleh kaum muda dan remaja putri (Wahyono, 1983). Kenyataan lain yang banyak dijumpai ialah kecenderungan o kalangan remaja indonesia untuk meniru gaya hidup mewah, dan perilaku yang sedang mewabah di negara-negara maju. Di kota-kota besar tampak banyaknya diskotik, rumah makan fastfoodkelas atas yang menawarkan makanan dan pelayanan berharga mahal dengan sasaran utama para remaja. dan bila peng- ama tan dilakukan lebih jeli lagi ternyata tempat-tempat tersebut memang dijejali oleh konsumen remaja.

Produk-produk yang dipandang sebagai lambang dan simbol status of kalangan remaja sangat mempengaruhi kebutuhan dan sikap hidup mereka. Loudondan Bitta (1984) menyatakan bahwa remaja adalah kelompok yang berorientasi konsumtif, karena kelompok ini suka mencoba hal-hal yang dianggap baru. Sebagai bagian dari masyarakat yang orientasinya tinggi, remaja semakin sadar akan produk-produk baru dan bermerek. Remaja akan cenderung meniru modemode baru. Pola perilaku ini diperkuat dengan menjamurinya majalah remaja. iklan, dan media yang lain yang langsung maupun tidak langsung mengeksploitasi gaya hidup mewah secara mencolok. Tanpa disadari hal tersebut mendorong seseorang untuk membeli dan membeli terus sehingga menyebabkan remaja semakin terjerat dalam perilaku konsumtif.

Hadipranata (dalam Nashori,1991) mengamati bahwa wanita mempunyai kecenderungan lebih besar untuk berperilaku konsumtif dibanding pria. Hal ini disebabkan konsumen wanita cenderung lebih emosional, sedang konsumen pria lebih nalar. Dalam hal jumlah uang yang dibelanjakan. Kefgen dan Spechl (Phares, 1976) menemukan bahwa remaja putri membelanjakan uangnya hampir dua kali iebih banyak dari pada remaja pria. Reynold. Scott, dan Warshaw (1973) menambahkan bahwa remaja putri usia antara 16 sampai dengan 19 tahun membelanjakan uangnya lebih banyak untuk keperluan menunjang penampilan diri seperti: sepatu. pakaian, kosmetik, dan asesoris.

\section{TELAAH PUSTAKA}

Yayasan Lembaga Konsumen fndonesia memberikan batasan konsumtivisme. 
yaitu kecenderungan manusia untuk menggunakan konsumsi tanpa batas, dan manusia lebih mementingkan faktor keingingan daripada kebutuhan (Mahdalela, 1995). Hal ini sejalan dengan pendapat Dahlan (1978) yang mengartikan konsumtivisme sebagai kehidupan mewah dan berlebihan, penggunaan segala hal yang dianggap paling mahal yang memberikan kepuasan dan kenyamanan fisik sebesar-besarnya. Konsumtivisme memberikan pengertian bahwa pola hidup manusia dikendalikan dan didorong oleh suatu keinginan untuk memenuhi has rat kesenangan semata-mata (Grinder, 1978). Lebih jauh dikemukakan oleh Sachari (1984) bahwa konsumtivisme terjadi karena masyarakat mempunyai kecenderungan materialistik, hasrat yang besar untuk memilikı benda-benda tanpa memperhatikan kebutuhannya. Ali (1983) menambahkan bahwa masyarakat tidak lagi mengenali kebutuhan yang sejati, namun justru selalu tergoda untuk memuaskan keinginannya yang semu agardisebut orang modern.

Tinjauan mengenai perilaku konsumtif perlu ditelusuri melalui pemahaman mengenai perilaku konsumen. Perilaku konsumen dalam membeli barang dipengaruhi oleh banyak faktor yang pada intinya dapat dibedakan menjadi dua faktor, yaitu faktor eksternal dan faktor internal (Engel, Kollat, dan Blakwell, 1973; Kottler, 1982; Swastha dan Handoko, 1987). Faktor eksternal meliputi: kebudayaan dan kebudayaan khusus. kelas sosial, kelompok sosial dan kelompok referensi, serta keluarga. Kebudayaan yang tercermin daiam cara hidup, kebiasaan dan tindakan dalam permintaan bermacam-rnacam barang di pasar sanga: mempengaruhi perilaku konsumen. Kebhınekaan kebudayaan datam satu daerah, banyaknya kelompok etnik akan membentuk pasar dan perilaku yang berbeda-beda. Pengaruh kebudayaan yang kual terhadap perilaku membeli telah dibuktikan oleh Loudon dan Bitta (1984) yang menemukan bahwa perilaku membeli dapat diramalkan dari nilai-nilai bud aya yang dipegang konsumen.

Kelas sosial adalah kelompok yang terdiri atas sejumlah orang yang mempunyai kedudukan yang seimbang dalam masyarakat, memegang nilai-nilai, mempunyai minat, dan menampikan perilaku yang mirip (Mangkunegara dan Prabu, 1988). Pendapat yang dikemukakan oleh Swastha dan Handoko (1987) menyatakan bahwa kelas sosial yang terbagi dalam kelas sosial atas, menengah, dan bawah, membedakan diri dalam kesukaan membaca majalah, kegiatan mengisi waktu luang, selera makan, dan perhatian terhactap mode, serta sikap dakam menerima inovasi baru. Interaksi seseorang di dalam kelompok sosial akan berpengaruh langsung pada pendapat dan seleranya, sehingga akan mempengaruhi pemilihan produk atau merk barang (Swastha dan Handoko, 1987). Sementara seseorang juga akan melihat kelompok referensinya dalam berperilaku menentukan produk yang dikonsumsinya. Kelompok referensi ini lebih kuat pengaruhnya pada seseorang karena akan membentuk kepribadian dan perilakunya. Keluarga seb agai bagian dari fa k or eksternal mempunyai pengaruh yang sangat besar dalam pembentukan sikap dan perilaku anggotanya, termasuk dalam pembentukan keyakinan dan berfungsi langsung dakam menetapkan keputusan konsumen (Loudon dan Bitta, 1984).

Faktor internal yang berpengaruh pada perilaku konsumtif ialah motivasi dan harga diri, pengamatan dan proses belajar, kepribadian dan konsep diri. Motivasi merupakan pendorong perilaku orang, tidak terkecuali dalam melakukan pembelian atau penggunaan jasa yang tersedia of pasar. Sementara harga diri berpengaruh pada perilaku membefi, orang-orang yang harga dirinya rendah akan cenderung lebih mudah dipengaruhi daripada orang-orang yang harga dirinya 
tinggi (Sears, Freedman, dan Peplau, 1992). Sebelum seseorang mengambil keputusan untuk membeli suatu produk, ia akan mendasarkan keputusannya pada pengamatan yang dilakukan atas produk tersebut. Lebih Jauh Howard dan Weth (1960) menyatakan bahwa pembelian yang dilakukan konsumen juga merupakan suatu rangkaian proses belajar. Bila ada pengalaman masa lalu yang menyenangkan dengan suatu produk yang dibelinya, akan menentukan keputusan untuk membeli lagi barang tersebut akan cenderung dilakukan lagi di masa yang akan datang. Sebaliknya, pengalaman yang kurang menyenangkan, akan memberi pelajaran bagi konsumen untuk tidak membeli produk yang sama di kala yang berbeda (Swastha dan Handoko, 1987; Mangkunegara dan Prabu, 1988).

Hal yang sifatnya internal lainnya yang berpengaruh pada keputusan membeli ialah kepribadian dan konsep diri. Kepribadian. menurut Hawkin, Coney. dan Bert (1980), sangat berpengaruh pada perilaku pengambilan keputusan untuk membeli produk: minuman, mobil, warna pakaian, dan kegiatan yang sifatnya rekreasional.

Locus of Control (LOC) dikemukakan oleh Rotter yang menggambarkan keyakinan seseorang mengenai sumber penentu perilakunya (Jung. 1978). Sarason (1976) berpendapat serupa, bahwa LOC merupakan suatu konsep tentang bagaimana individu memandang dirinya dalam mengontrol kehidupannya. Para ahli membedakan $L O C$ menjadi dua, yaitu: $\angle O C$ internal dan $\angle O C$ eksternal. Karakteristik orang dengan $\angle O C$ internal ialah mempunyai keyakinan bahwa individu sendirilah yang bertanggung jawab atas kesuksesan atau kegagalan yang dialaminya. Sedang orang dengan LOCeksternal mempunyai karakteristik bahwa ia berkeyakinan apa yang terjadi d luar dirinya baik keberhasilan maupun kesengsaraan lebih disebabkan oleh: nasib, keberuntung- an, dan kesempatan, serta kekuasaan orang lain, dan bukan merupakan tanggung Jawabnya (Jung, 1978).

LOC sifatnya bukan tpologik. tetapi kontinyu, internalitas seseorang yang tinggi akan disertai oleh melemahnya ekstemalitas pada diri yang bersangkutan. Sebaliknya. pada diri orang yang karakteristik LOCnya cenderung eksternal maka akan diikuti dengan melemahnya karakteristik intemal. $\angle O C$ bukan merupakan trats yang sifatnya stabil, karena kejadian-kejadian yang sangat menggoncangkan kejiwaan seseorang dapat menpengaruhi internalitas-eksternalitas atau orientasi $L O C$ yang bersangkutan.

Robinson dan Shaver (1974) mengelompokkan faktoryang mempengaruhi perkembangan $L O C$ menjadl dua, yaitu: Episodic Antecedents, yaitu kejadian-kejadian yang mempengaruhi perkembangan $\angle O C$, seperti kecelakaan, atau kematian seseorang yang dicintainya, dan Accumulation Antecedents. yaitu faktor-faktor seperti: diskriminasi sosial, perasaan tidak berdaya, dan pole asuh orangtua.

Masa remaja merupakan masa peralihan dari masa kanak-kanak ke masa dewasa. Karakteristik masa ini ialah kondisi psikis remaja yang masih sangat belum mantap sehingga sangat mudah untuk dipengaruhi. Kenyataan yang demikian mendorong Jatman (1987) untuk mengemukakan pendapatnya bahwa remaja Indonesia merupakan kelompok sasaran yang potensial untuk memasarkan produk-produk industri. Konsumen remaja mempunyai kemampuan membeli yang tinggi, sebab pada umumnya remaja dalam berpakaian, berdandan, gaya potongan rambut, tingkah laku, kesenangan musik, mempunyai karakteristik tersendiri, dan kebanyakan dari mereka membelanjakan uangnya untuk keperluan tersebut (Monks, Knoers dan Haditono, 1995). Keadaan yang demikian membuat remaja mempunyai pola konsumsi yang menunjuk- 
kan sifat eksklusif dengan citra yang mahal, lebih mewah. Manifestasi penampilannya dapat berupa remaja dengan mode mutakhir, memberi kesan berasal dari kelas sosial yang lebih tinggi. Gejala ini menimbulkan perilaku konsumtif di kalangan remaja. Untuk mengikuti kecenderungan konsumtif, remaja membutuhkan uang yang jumlahnya tidak sedikit, sehingga perilaku konsumtif lebih terlihat pada remaja dengan uang saku yang cukup banyak. Barclay (1980) merlyatakarı bahwa remaja yang mempunyai daya konsumsil besar, biasanya berasal dari keluarga di mana dapat diperoleh uarig dengan mudah.

Lingkungan ekonomi sarigat mempengaruhi perilaku seseorang, dan bagamana individu bereaksi atau merigadakan penyesuaian dengan lirıgkungannya juga sangat dipengaruhi oleh $L O C$ individu tersebut. Rotter menyatakarı bahwa perilaku seseorang ditentukan oleh interaksi antara harapan, nilai-nilai yang ada pada seseorarig. serta lingkungarl di mana la berada.

Harapan-harapan ini dapat menentukan kontrol seseorang apakah sebagai penguat pada koritrol internal atau eksternal. Pada perilaku konsumtit seseorang berperilaku membeli karena mempunyai harapan tertentu. misaknya ingin dihargai. Glock (Loudon \& Bitta, 1984) dalam penelitiannya menemukan bahwa konsumsi yang berlebihan sangat ditentukan oleh sikap mudah terpengaruh oleh kelompok refererisi. Remaja sebagai konsumen yang masih dalam masa transiși mempunyal karakteritsk mudah dipengaruhi oleh kelompok sebaya dan kelompok referensinya serta memiliki kontrol eksternal lebih tinggi dari pada kontroı internal.

\section{HIPOTESIS}

Hipotesis yang dikemukakan dalam penelitian ini lalah ada perbedaan perikaku konsumtif ditirijau dari LOCdan uarıg saku pada remaja putri di sekolah menengah umum. Remaja putri ber-loc eksternal memiliki perilaku konsumtif lebih tinggi dibandirıg remaja putri yang ber-loc internal.

\section{METODE}

Pada penelitian ini digunakan dua macam skala yaitu: Skala Perilaku Konsumtif dan Skala Locus of Control. Skala pertama tersusun atas tiga aspek yaitu: aspek impulsive buying, aspek non rational buying. darı aspek wastefur buying. Jumlah aitem pada skala ini sebanyak 30 , dengan indeks validitas kriteria internal antara $r_{u}=0.426$ sampai derıgan $r_{\mathrm{z}}=0,7613$. Reliabilitas skala Ini diperoleh dengarı merıggunakan uji reliabilitas alpha $=0,9443$. Skala kedua ialah Skala IPC Locus of Control, pertama kali diterjemahkan ke dalam bahasa Indonesia oleh Munaridar (1990) dan masih terus dalam penyempurnaan. Skala ini tersusun atas tiga sub-skala, yaitu: sub-skala internal, sub-skala Powerful Others, darı sub-skata Chance. Pada masing-masing sub-skala terdiri atas delapan aitem, sehirıga secara keseluruhan Skala IPC Locus of Control ini berjumlah 24 aitem. Beberapa uil coba telah dilakukan untuk melihat validitas dan reliabilitas skala IPC LOC. D antaranya ialah Hendy (1985) menemukan saling hubungan antar sub-skala dan mencatat korelasi sebesar $r=-0.497$ untuk sub-skala I dan subskala $P, r=-0.729$ untuk sub-skala I dan sub-skala $C_{1}$ dan $r=0.576$ untuk sub-skala $P$ dan sub-skala $C$, semuarlya sangat signifikan ( $p<0.001)$. Hasil irli sesuai dengarı harapan bahwa sub-skala $P$ dan $C$ berkorelasi tinggi, karena sama-sama dirancang untuk mengungkap kecenderungan eksternal. Peneliti di atas juga membuktikan adanya validitas diskriminan pada sub-skala internal dan sub-skala eksternal.

Reliabilitas yang diperoleh dengan menggunakan teknik Hoyt menunjukkan 
indeks sebesar $r_{11}=0.750$. Untuk keperluan perolehan informasi yang lebih banyak penelitian ini juga menggunakan alat untuk mengungkap besarnya uang saku yang dimiliki subjek. Uang saku diperinci ke dalam; besarnya uang saku per bulan, pengeluaran uang saku, dan sisa uang saku per bulan.

Subjek penelitian ialah siswi-siswi se buah sekolah menengah umum swasta d Kota Madya Yogyakarta. Mereka sebelumnya berjumlah 88 orang yang tengah duduk di kelas II. Pemilihan subyek dalam penelitian ini didasarkan pada tingkat usia berkisar antara 16 sampai dengan 18 tahun, yaitu rentang waktu yang termasuk masa remaja dengan karakteristik psikologis yang spesifik. Subjek semuanya berjumlan 116 orang, tetapi setelah dikategorikan ke dalam salah satu orientasi locus of control maka terdapat 28 siswi yang tidak dapat dimasukkan dalam kategori tertentu, sehingga tidak dapat dikutsertakan d dalam analisis data.

Untuk mengetahui perbedaan perflaku konsumtit berdasar LOC pada remaja putri digunakan program analisis kovarıansı.

\section{HASIL}

Data yang diperoleh dari alat pengumpul data meliputi data mengenai perilaku konsumtif. LOC, dan keadaan mengenai ekonomi subjek. Deskripsi data digambarkan dalam tabel berikut in.

Tabel 1

Deskripsi Subyek Penelitian

\begin{tabular}{|l|c|c|c|c|c|c|c|}
\hline \multirow{2}{*}{$\begin{array}{c}\text { Orientasi } \\
\text { LOC }\end{array}$} & \multicolumn{2}{|c|}{ Sumber Keuangan } & \multicolumn{3}{c|}{ Tempat Tinggal } & \multicolumn{2}{c|}{ Uang Tambahan } \\
\cline { 2 - 8 } & Ortu & Oru+S & K/AS & Rmh. & Npg. & Dpt. & Tdpt. \\
\hline \multirow{3}{*}{$\begin{array}{l}\text { Internaf } \\
\text { Eksternal }\end{array}$} & 43 & 2 & 18 & 26 & 26 & 1 & 30 \\
& 40 & 3 & 17 & 23 & 23 & 3 & 27 \\
\hline Total & 83 & 5 & 35 & 49 & 4 & 37 & 57 \\
\hline
\end{tabular}

Keterangan:

Ortu : Orang tua
Ortu+S $:$ Orang tua dan Saudara
KAS : Kos/Asrama
Rmh. : Rumah orang tua sendirj
Npg. : Menumpang pada rumah saudara
Dput : Mendapabtidak mendapat uang saku tambahan

Tabel di atas menunjukkan jumlah subjek yang dikategorikan dalam orientasi locus of control, asal atau sumber keuangan, keberadaantempat tinggal, dan kepemilikan uang tambahan.
Hasil penelitian secara deskriptif juga menunjukkan tingkat perbedaan skor perilaku konsumtif. jumlah uang keluar, jumlah uang tambahan dan sisa uang. Data penelitian bahwa subjek yang termasuk ke dalam 
kelompok locus of control eksternal memiliki rata-rata perilaku konsumtif yang lebih tinggi dari pada kelompok berlocus of control internal $\left(M_{\text {siks }}=79,023<M_{\text {irg }}=59,067\right)$. Juga terlihat bahwa kelompok eksternal memiliki rata-rata uang bebas yang jumlahnya lebih besar daripada yang dimiliki kelompok internal $\left(\mathrm{M}_{\mathrm{UBek \textrm {K }}}=\mathrm{Rp} .41 .744,00>\mathrm{M}_{\mathrm{UB}}=\right.$
Rp 20.356,00), sementara untuk jumlah sisa uang yang dimiliki rata-rata kelompok eksternal memperoleh lebih kecil dibanding kelompok internal $\left(\mathrm{M}_{\mathrm{USeks}}=\mathrm{Ap} .6 .326,00<\right.$ $M_{\text {USm }}=$ Rp. 22.178,00).

Hasil analisis data yang diperofeh ringkasan dalam tabel berikut ini.

Tabel 2

Deskripsi Analisis Penelitian

\begin{tabular}{|c|c|c|c|c|c|}
\hline S.V. & $J K$ & $\omega$ & MK & $F$ & $\rho$ \\
\hline $\begin{array}{l}\text { LOC } \\
\text { Ung. Beb } \\
\text { Ung. Sis. } \\
\text { Sisa }\end{array}$ & $\begin{array}{r}1.682 .467 \\
1.174 .564 \\
739.763 \\
5.086 .432\end{array}$ & $\begin{array}{r}1 \\
1 \\
1 \\
84\end{array}$ & $\begin{array}{r}1.682 .467 \\
1.174 .467 \\
739.763 \\
60.547\end{array}$ & $\begin{array}{c}27.788 \\
19.393 \\
12.218 \\
-\end{array}$ & $\begin{array}{l}0.0 \\
0.0 \\
0,0 \\
-\end{array}$ \\
\hline Total & 15.101 .091 & 87 & 173.576 & - & - \\
\hline
\end{tabular}

Berdasar perhitungan dengan menggunakan teknik analisis dapat diketahui bahwa ada perbedaan perilaku kosumtif yang signifikan antara siswa dengan $\angle O C$ internal dan siswa dengan $\angle O C$ eksternal ( $F=$ 27.788; $p<0.001$ ). Nilai rerata perilaku konsumtif untuk kelompok $L O C$ internal $\left(\mathrm{M}_{\mathrm{mi}}=\right.$ $59,067)$ lebih rendah dari pada nilai rerata untuk kelompok $\angle O C$ eksternal $\left(\mathrm{M}_{\text {ekg }}=\right.$ 79,023 ). Oleh karena itu, hipotesis yang menyatakan ada perbedaan perilaku konsumtif antara siswa yang memiliki $\angle O C$ internal dengan perilaku konsumitif pada kelompok siswa ber-LOCeksternal diterima.

\section{PEMBAHASAN}

Perbedaan perilaku konsumtif antara kelompok siswa berLOCintemal dan kelompok
ber-LOC eksternal dimungkinkan karena perbedaan karakteristik yang ada pada $L O C$ itu sendiri. Petri (1980) menyatakan bahwa individu yang ber-LOC eksternal memiliki sikap patuh, lebih conformterhadap otoritas atau pengaruh-pengaruh yang ada, lebih mudah dipengaruhi dan tergantung pada petunjuk orang lain (Sarason, 1976). Sementara individu ber- $\angle O C$ internal mempunyai karakteristik lebih mandiri, lebih ulet, mempunyai daya tahan yang kuat serta lebih tahan dalam menghadapi pengaruh sosial (Seeman dan Evans, dalam Zimbardo \& Ruch, 1976). lebih mampu menunda pemuasan, tidak mudah terpengaruh, dan lebih mampu menghadapi kegagalan (Leftcourt dalam Wolfe \& Robertslaw, 1982), lebih aktif dan ulet dalam mencari dan menggunakan 
informasi yang relevan untuk menguasai keadaan (Phares, 1976).

Glock (Loudon \& Bitta. 1984) menandaskan bahwa pada umumnya pola konsumsi yang beriebihan sangat ditentukan oleh sikap mudah terpengaruh oleh kelompok referensi. Dapat dikatakan kecenderungan untuk berperilaku konsumtif pada remaja dipengaruhi oleh karakteristik khas yang ada pada diri remaja sendiri, yaitu ketergantungan yang kuat pada kelompok sebaya. Locus of contr olmerupakan salah sau komponen kepribadian pada individu, tidak terkecuali pada diri remaja. Dengan ciri-ciri karakteristik LOCeksternal, sifat mudah terpengaruh masih dominan pada diri remaja. Hal ini sesuai dengan pendapat Monks dkk (1995) yang menyatakan bahwa remaja yang peka terhadap pengaruh kelompok adalah remaja yang memiliki kontrol eksternal lebih tinggi dari pada kontrol internalnya.

Pad a kelompok internal ditemukan nilai rata-rata perilaku konsumlif yang lebih rendah, atau kurang konsumtif perilakunya ( $M_{\text {min }}$ $=59,07)$. Hal ini dimungkinkan karena kepribadian yang dimilikinya mampu mengendalikan diri untuk tidak mudah terpengaruh oleh berbagai tawaran hadiah, diskon, atau model penawaran yang gencar dilakukan di media masa maupun secara langsung. Dengan kemandirian yang dihayatinya, remaja dengan LOCinternal ini mampu membuat skala prioritas berdasar kepentingan. Tidak tertutup kemungkinan bahwa remaja $L O C$ intemal ini mengekspresikan dirinya tidak melalui penampilan yang trendydengan berpakaian. kosmetik, atau perhiasan, tetapi melalui unjuk kemampuan di bidang lain. misal prestasi akademik, olah raga, ketrampilan, dan hobi, sehingga mereka tidak gampang terbujuk membeli barang-barang yang berhubungan dengan penampilannya.

Perilaku konsumtif membutuhkan uang dalam jumlah yang melebihi dari kebutuhan biasa. Hasil lain penelitian ini menunjukkan bahwa uang bebas dan uang sisa mempunyai kontribusi dalam menentukan perilaku konsumlif. Semakin besar jumlah uang be bas yang dimiliki remaja, semakin konsumtif perilaku remaja ini. Besarnya pengeluaran yang dibelanjakan akan mempengaruhi jumlah uang yang disirnpan. Semakin besar pengeluaran, semakin kecil uang yang dapat ditabung.

Perilaku konsumtif pada subjek penelitian ini termasuk tinggi $\left(M_{r p}=60\right)$ dibanding mean empirik $(M=68,86)$ pada skala perilaku konsumtif. Hurlock (1993) menyatakan bahwa kebanyakan remaja menganggap bahwa penampilan dan gaya hidup masih merupakan simbul status sosial yang lebih tinggi di dalam kelompoknya. Dengan demikian muncullah sikap bersaing dalam penampilan diri melalui pakaian, sepatu. gaya rambut, dan asoseris lainnya.

Hal yang menarik untuk dikaji dalam penelitian ini adalah kelompok siswa yang lidak dapat dikategorikan ke dalam salah satu jenis locus of control, baik itu $L O C$ internal ataukah LOC eksternal. Jurniah mereka sebanyak 28 orang atau sebesar $24,13 \%$. Bagairnanakan pola perilaku konsums: kelompok ini? Jawaban dari pertanyaan ini tidak terungkap dari hasil penelitian. Pola perilaku mereka yang khas boleh jadi memainkan peran dalarn penyusunan strategi pemasaran alternatif.

\section{PENUTUP}

Penelitian ini menghasikan simpulan bahwa ada perbedaan perilaku konsumtif yang signitikan antara remaja putri dengan LOC internal dan remaja putri dengan LOC eksternal. Rernaja putri dengan LOC eksternal memiliki perilaku konsumtif lebih tinggi dibanding rernaja dengan LOC internal. $\square$. 


\section{DAFTAR PUSTAKA}

Ali. 1993. Pola Hidup Konsumtif: Antara Kapitalisme darı Nafsu Prestise. Ekonomika. Ed. 1, th. XVIl. Yogyakarta.

Barclay, D. 1978. Understanding The City. Child. New York Collier Book Company.

Dahlan, A.M. 1978. Sosialisasi Hidup Sederhana. Prisma No. 10. Jakarta.

Engel, J.F., Kollet, D.T., Blackwell, R.D. 1973. Consumer Behavior. Second Edt. New York: Holt, Rinehart and Winstons, Inc.

Grinder, R.E. 1978. Adolescent. New York: John Wiley \& Sons.

Hawkins, D.C. Coney, K.A. and Bert, R.J. 1980. Consumer Behavior: Implication forMarketingStrategy. Texas: Business Publication, Inc.

Howard, J.A. and Seth, J.N. 1969. The Theory of Buyer Behavior. New York: Appleton Century.

Jatman, D. 1987. Remaja Incaran Iklan. Ka daulatan Rakyat. 10 September. Yogyakarta.

Kottler, P. 1982. Markating Management. New York: Prentice-Hall Inc.

Loudon, D.L. and Bitta, D.N. 1984. Consumer Behavior: Concepts and Application. Second Edt. New York: McGrawHill.

Lubis, Y. 1987. Perilaku Konsumtif: Antara Gengsi dan Kenyataan. Gadis. no. 18. 20 Juli. Jakarta.
Moschis, G.P. and Churchill, G.A. 1979. An Analysis of Adolesence Consumer. Journal of Marketing no. 43.

Monks, F.J., Knoers, A.M.P. dan Haditono, S.R. 1995. Psikologi Perkembangan, Yogyakarta: Gadjah Mada University Press.

Nashori, F. 1991. Konsumtivisme Masyarakat Indonesia. Psikomedia. Ed. 7. Yogyakarta.

Phares, E.J. 1976. Locus of Control in Personality. New Jersey: General Learning.

Reynolds, S.H., Scott, S.O. and Warshaw, M.R. 1973. introduction to Marketing Management. Revisioned Edition. Illinois: Homewood trvin finc.

Robinson, J.D. and Shover, F.R. 1974. Measures of Social Psychological Attitudes. Michigar: A Survey Research Centre for Social Research.

Sarason, I.C. 1976. Personality: An Objective Approach. Second Edt. Washington: John Wiley and Sons.

Sachari, R.E. 1978. Adolesence. New York: John Wiley \& Sons.

Sears, D.O. Freedman, J.L. and Peplau. L.A. 1992. Psikologi Sosial (Terjemahan). Jilio 1. Jakarta: Erlangga.

Swastha, B dan Handoko, H. 1987. Manajemen Pemasaran: Analisis Perilaku Konsumen. Yogyakarta: Liberty.

Wahyono, A. 1983. Pola Hidup Sederhana: Mengapa Sulit Dicapai Keseragamannya. Kedaulatan Rakyat. 9 Maret 1983. Yogyakarta. 